\title{
ISOTOPE-GEOCHEMICAL CHARACTERISTICS OF HYDROCARBONS ON THE NORTH-WESTERN FLANK OF SOUTH CASPIAN BASIN
}

\author{
Feyzullayev A.A. \\ Institute of Geology and Geophysics of Azerbaijan National Academy of Sciences \\ 119, H. Javid Ave., Baku, Azerbaijan, AZ1143: fakper@gmail.com
}

Keywords: oil, gas, source rocks, organic matter, geochemistry, correlation, South Caspian basin
Summary. This paper details aspects of isotope-geochemical features for oil and gas on the $\mathrm{N}-\mathrm{W}$ flank of South Caspian basin (Gobustan, western Absheron regions and adjacent offshore area), where natural oil and gas seepages are associated with tectonic faults and mud volcanoes (MVs). Oils concerned with MVs are biodegraded, having predominantly naphthenic-paraffinic base and less than $0.5 \%$ sulfur content. Oil samples and hydrocarbon extracts of source rock were analyzed using gas chromatography, mass spectrometry and their combination (biomarker analysis). Oil-oil and oil-source rock correlations are used. The values of the complex biomarker parameters of selected oil samples correspond to Tertiary source rocks with the similar organic facies accumulated in deep-water conditions with some terrestrial contribution. Oils have low to moderate organic maturities (Ro $=0.75-0.85)$. Relationship between the isotope composition of carbon (ICC) for aliphatic and aromatic fractions of oils and rock extracts (oil-rock correlation) shows that the source of commercial oil reserves in the Productive series (lower Pliocene) is mainly Miocene deposits (Diatom, Chokrak and Upper Maykop strata). The source of gases is from the sedimentary cover as is evidenced by the $3 \mathrm{He} / 4 \mathrm{He}$ ratio values. They also have been derived from mixed marine organic-rich source facies. Such gas is not from the thermal destruction of oils. Calculated depth of oil source corresponds to 6.1-8.6 km (gas source - from 8.1 to $15.8 \mathrm{~km}$ ). The isotopically heavy ICC of $\mathrm{CO}_{2}$ in gases is most probably the microbial destruction of hydrocarbons at shallow depths (no deeper than $2 \mathrm{~km}$ ).

(C) 2019 Earth Science Division, Azerbaijan National Academy of Sciences. All rights reserved.

\section{Introduction}

The north-western flank of the South Caspian basin (SCB) includes Gobustan, western Absheron regions and adjacent offshore area (Fig. 1). This area is a strongly folded region with high density of development of structures and outcrops with a wide stratigraphic range (from Pliocene to Paleogene). Natural oil and gas surface seepages associated with tectonic faults and mud volcanoes are widely developed.

The purpose of this paper is to detail different aspects of isotope-geochemical features of oil and gas in this region.

\section{Results of studies and discussion}

\subsection{Oil and gas seepages}

\subsubsection{Oil seeps}

Oil seeps concerned with mud volcanoes (MV) are biodegraded except for the oil at the northwesternmost volcano, Demirchi, at the offset of the Greater Caucasus (Fig. 2). All oils have predomi- nantly naphthenic-paraffinic base and less than $0.5 \%$ sulfur content.

The isotopic composition of carbon (ICC) of crude oil ranges from -28.2 to $-25.0 \%$ and the pristine/phytane $(\mathrm{Pr} / \mathrm{Ph})$ ratio ranges from 0.9 to 2.0. The studied oil seeps from MVs are classified into two types: isotopically heavy and isotopically light. The gas chromatography - mass spectrometry (GCMS) traces show low diasteranes and an almost equal distribution of $\mathrm{C}_{27-29}$ sterane compounds, though $\mathrm{C}_{28}$ sterane is often slightly dominant.

\subsubsection{Gas seepages}

Gases play an important role in mud volcanoes process. The source of these significant gas volumes is from the sedimentary cover as is evidenced by the ${ }^{3} \mathrm{He} /{ }^{4} \mathrm{He}$ ratio values, which vary within $(0.28-9.0) * 10^{-7}$ (average $1.2 * 10^{-7}$ ).

Methane dominates in all the samples of the MV gases (89.1-99.5\%). There are small amounts of $\mathrm{CH}_{2-6}, \mathrm{CO}_{2}, \mathrm{~N}_{2}, \mathrm{He}$ and $\mathrm{Ar}$ (Valayev and Grinchenko, 1984). 


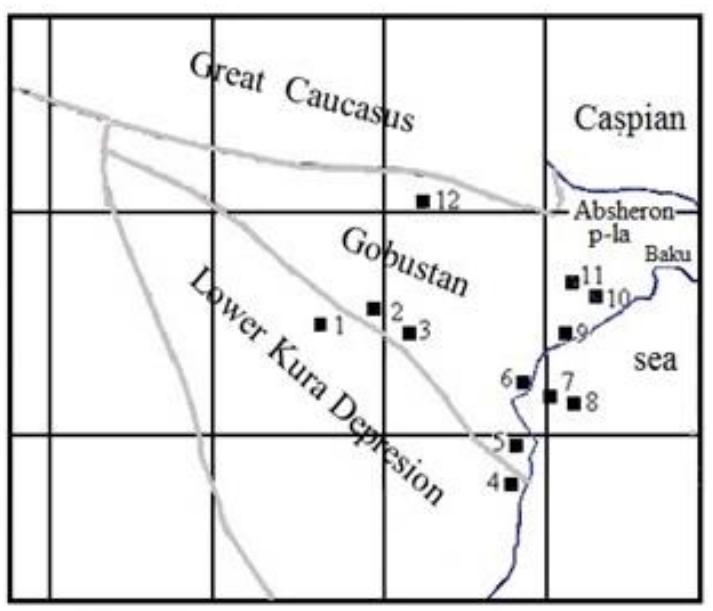

Figure 1. Scheme of location the studied region, petroleum fields and mud volcanos: 1 - Kalamaddyn; 2 - Hajiveli; 3 - Umbaki; 4 - Pirsaat; 5 - Dashgil; 6 - Kyanizadag; 7 - Sangachaldeniz; 8 - Duvanny-deniz; 9 - Garadag; 10 - Guzdek; 11 - Kergez; 12 - Jangi (mud volcano)
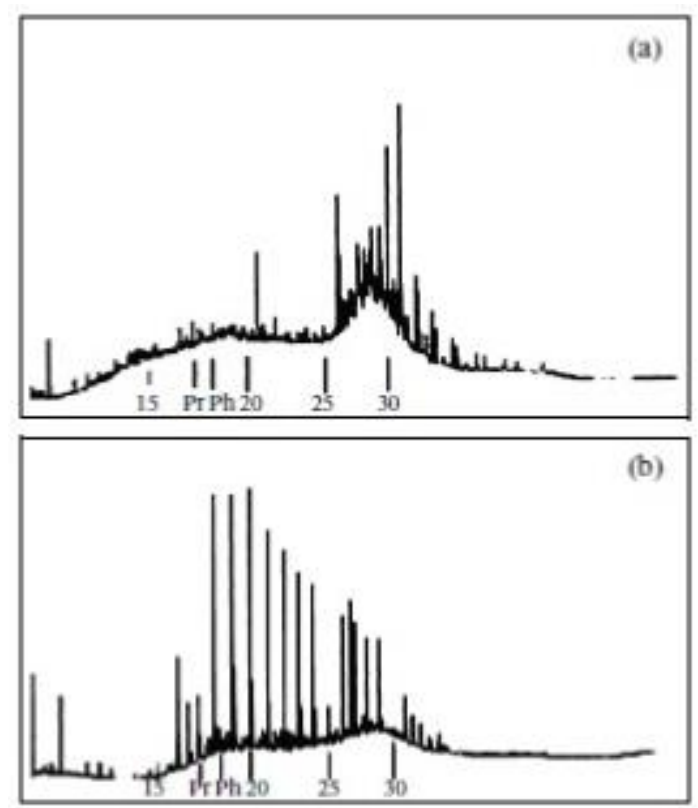

Figure 2. Examples of gas-liquid chromatograms of the saturated fraction of oils from mud volcanoes in Azerbaijan: (a) biodegraded oil (Kyrlykh MV) and (b) non-biodegraded oil (Demirchi MV)

The isotope compositions of carbon of methane and ethane display significant variability: respectively, -58.4 to $-39.4 \%$ and -23.3 to $-29.6 \%$. The isotopically lightest samples are interpreted as a mixed biogenic and thermogenic gases. The isotopically heaviest samples are indicative of a thermogenic origin (Fig. 3).

The $\mathrm{CO}_{2}$ concentration in gases of MVs ranges from 0.05 to $18.2 \%$. Values of $\delta^{13} \mathrm{C}\left(\mathrm{CO}_{2}\right)$ from more than 80 examined MVs vary widely: from -49.6 to $+25.6 \%$ and indicate the presence of multiple sources of $\mathrm{CO}_{2}$. The rarely encountered isotopically super-heavy $\mathrm{CO}_{2}(>+5 \%)$ has special interest.

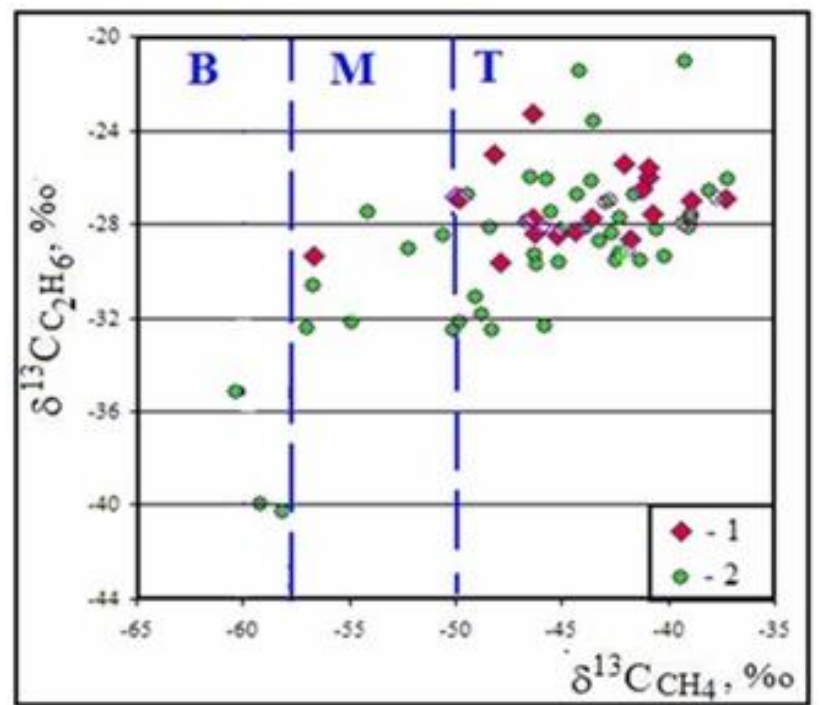

Figure 3. ICC of $\mathrm{CH}_{4}$ vs. ICC of $\mathrm{C}_{2} \mathrm{H}_{6}$ in gases of mud volcanoes (1) and petroleum

\subsection{Reservoir oils and gases}

\subsubsection{Reservoir oils}

Examination of oils was carried out using gas chromatography and mass-spectrometry techniques and their combination (biomarker analysis). Some oils are mixtures of biodegraded and nonbiodegraded oils. Unaltered oils have similar n-alkane distributions, indicating an algae contribution typical for lacustrine, lagoonal or pelagic sedimentation environments.

The pristane / phytane $(\mathrm{Pr} / \mathrm{Ph})$ ratio is between 1.3 and 1.5 for the majority of oils. Such values are typical for oils generated by source facies of marine origin when the oxygen-enriched photic zone is located above anoxic water mass and sediments. For some samples values of $\mathrm{Pr} / \mathrm{Ph}$ ratio were found to be below 1.3, apparently suggesting more reducing conditions in the water layer, less thermal maturity or, more likely, biodegradation impact.

Pristane/n- $\mathrm{C}_{17}$ and Phytane/n- $\mathrm{C}_{18}$ ratios (Fig. 4) suggest that the source rocks were in transition between oxidizing and reducing conditions with similar molecular characteristics. Variation in isoprenoid/n-alkane ratio values is controlled exclusively by the extent of biodegradation. These parameters suggest that oils were generated by several source rocks with similar facies.

The carbon preference index (CPI) values, derived from gas chromatographic analyses (Marzi et al., 1993), change in the narrow range $(1.02 \pm 0.02)$, indicating moderate input of terrestrial organic material.

Gross composition of oils (Fig.5) indicates that they are sourced from similar organic facies.

Sterane distributions $\left(\mathrm{C}_{27}, \mathrm{C}_{28}\right.$ and $\left.\mathrm{C}_{29}\right)$ show close similarity between studied oils (dispersion is 
around 3\%), thus also indicating, that the oils have been generated by similar source facies (Fig. 6-8).

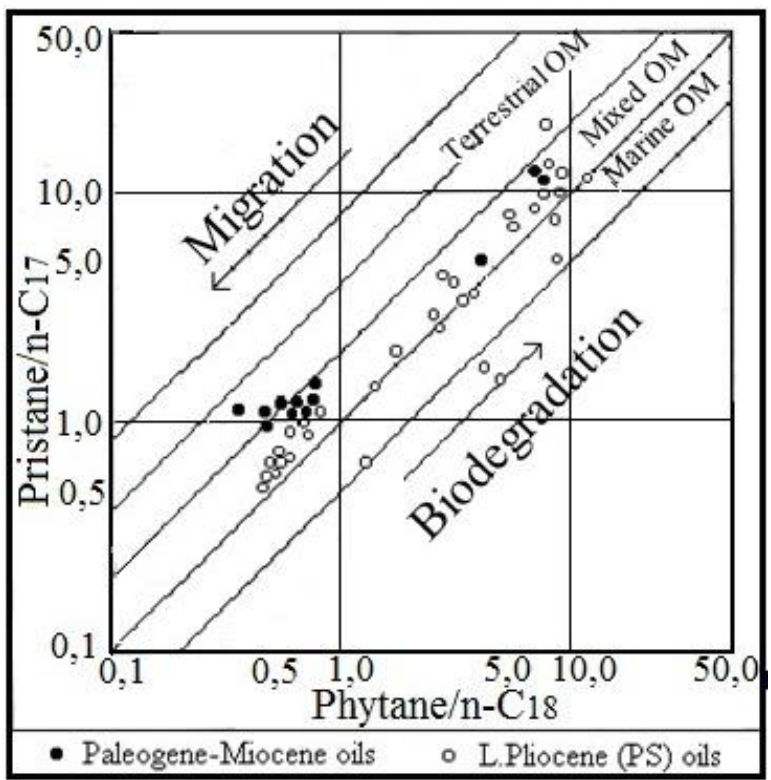

Figure 4. Crossplot of Pristane/n- $\mathrm{C}_{17}$ vs. Phytane/n- $\mathrm{C}_{18}$ in oils

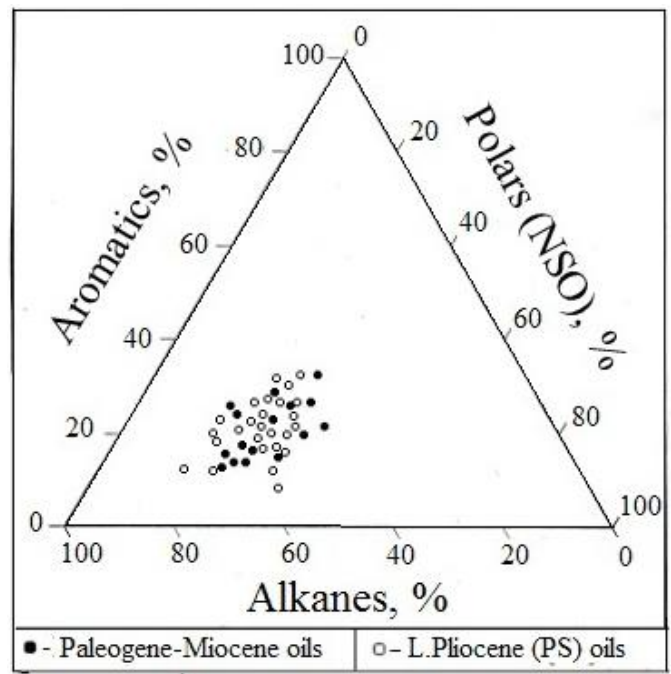

Figure 5. Triangle diagram of the oil group composition from Paleogene-Miocene and Low Pliocene reservoirs

The values of other complex biomarker parameters, such as $\mathrm{C}_{28} / \mathrm{C}_{29}$ sterane ratio, hopane/(hopane +moretane) ratio, content of oleanane and gammacerane, tricyclic and pentacyclicterpanoids, testify to Tertiary source rocks with similar organic facies accumulated in deep-water conditions with some terrestrial contribution. Moderate input of terrestrial organic material is confirmed by the carbon preference index (CPI) values, derived from gas chromatographic analyses (Marzi et al., 1993), which change in the narrow range $(1.02 \pm 0.02)$. Norhopanes to hopanes ratio is low, typical for clastic source rocks.
Although all of the above biomarker indexes indicate the formation of oils from similar organic facies, the $\delta^{13} \mathrm{C}$ ratio of whole oils, varying between -27.52 and $-23.83 \%$ suggests their formation in different source rocks.

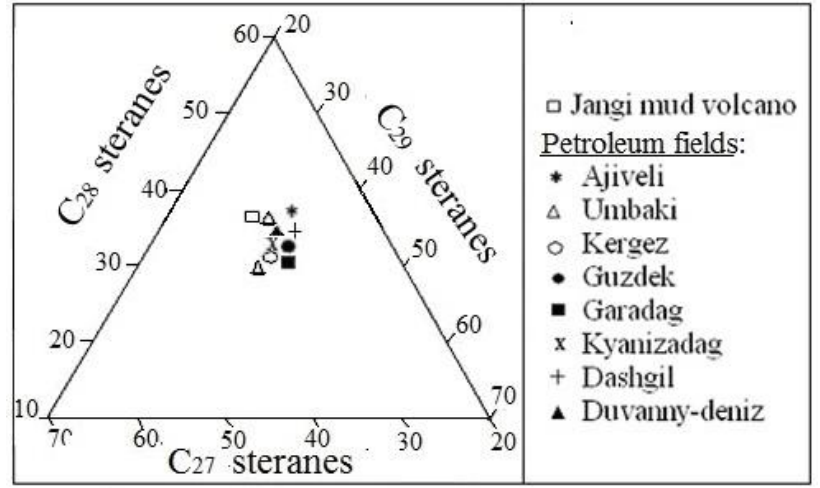

Figure 6. Relative percentage of $\mathrm{C}_{27}: \mathrm{C}_{28}: \mathrm{C}_{29}$ regular steranes in oils

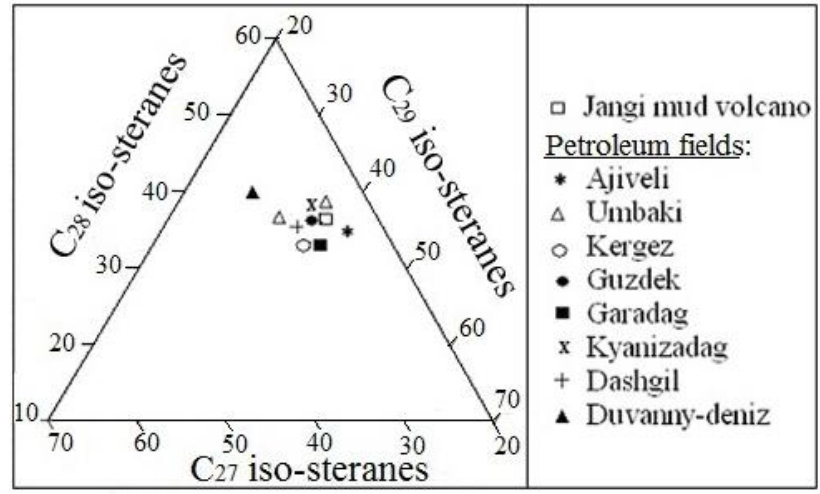

Figure 7. Relative percentage of $\mathrm{C}_{27}: \mathrm{C}_{28}: \mathrm{C}_{29}$ isosteranes in oils

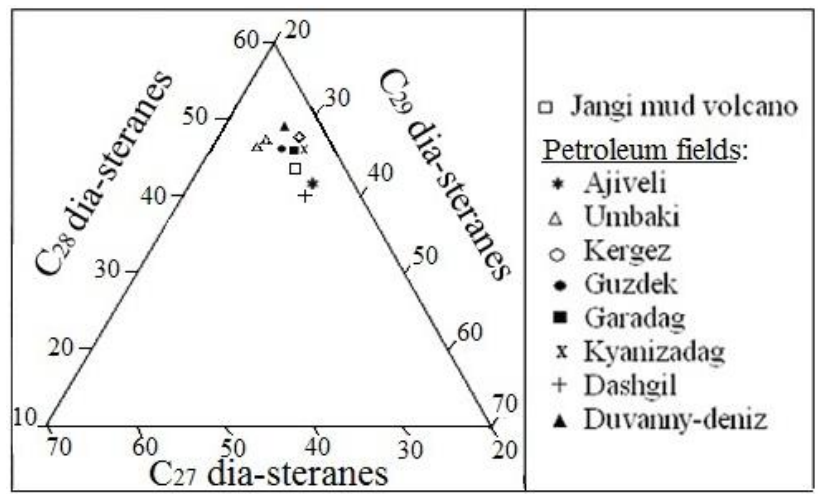

Figure 8. Relative percentages of $\mathrm{C}_{27}: \mathrm{C}_{28}: \mathrm{C}_{29}$ diasteranes in oils

The relationship between the ICC of aliphatic and aromatic fractions of oils and rock extracts (oilrock correlation) indicates that the source of commercial oil reserves in the Productive series is mainly Miocene deposits (Diatom, Chokrak and Upper Maykop strata) (Fig. 9). 


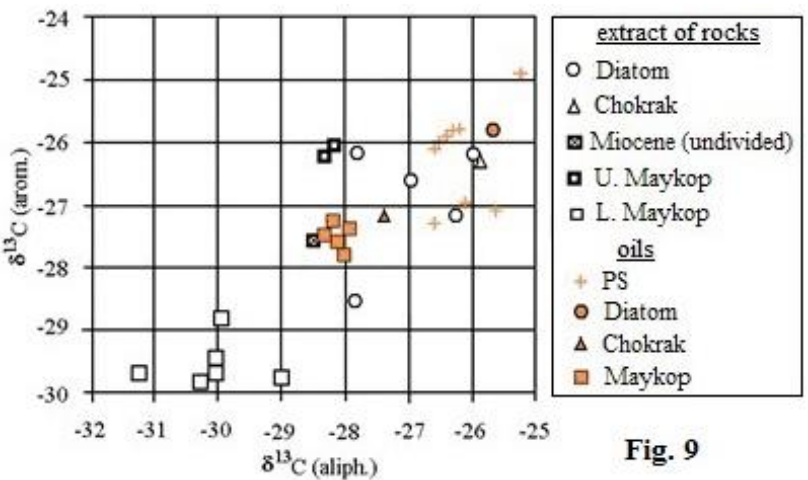

Figure 9. The relationship between the ICC of aliphatic and aromatic fractions of oils and rock extracts

\subsubsection{Reservoir gases}

17 gas samples were examined from 13 fields of the Gobustan and adjacent Absheron and offshore areas. All gases are associated with oil accumulations. The samples are taken from reservoirs occurring in the depth interval from 520 to $4268 \mathrm{~m}$ and cover wide geographic and stratigraphic ranges.

The natural gases display significant differences in both molecular and isotopic composition. Methane dominates in all samples $(89-99.8 \%)$. Gas wetness ranges from less than $1 \%$ (Sangachal-deniz field) to greater than $12 \%$ (Pirsaat field). The character of the gas wetness variability with depth most probably reflects the location in the section of peak oil generation and the zone of biogenic gases.

Values of the $\mathrm{iC}_{4} / \mathrm{nC}_{4}$ ratios vary in the range 0.36-4.4 and decrease with depth due to either thermal maturity as a result of the generation of $\mathrm{nC}_{4}$ or alteration through microbial processes, which preferentially remove $\mathrm{nC}_{4}$ and therefore cause an increase in the ratio.

Methane carbon isotopic composition ranges from 58 to $37 \%$ relative to the PDB standard. The stable carbon isotopic composition of ethane also displays a wide range. Unlike mud volcanoes, which are represented predominantly by thermogenic hydrocarbon gases, the gases of the petroleum fields have both thermogenic and biochemical origins, as well as being mixed (see Fig.3).

Examination of the dataset reveals an increasing tendency in the methane and ethane $\delta^{13} \mathrm{C}$ values with depth. Such a trend is consistent with increasing thermal maturity of gases. Due to vertical migration the introduction of isotopically heavier gas in the shallow section is observed.

As well as in mud volcanoes the presence of isotopically super-heavy $\mathrm{CO}_{2}$ was detected also in gases of petroleum fields. In gases of the petroleum fields this type of $\mathrm{CO}_{2}$ is found only to a depth of about $2 \mathrm{~km}$, regardless of the stratigraphic affiliation of the reservoir (Fig. 10).

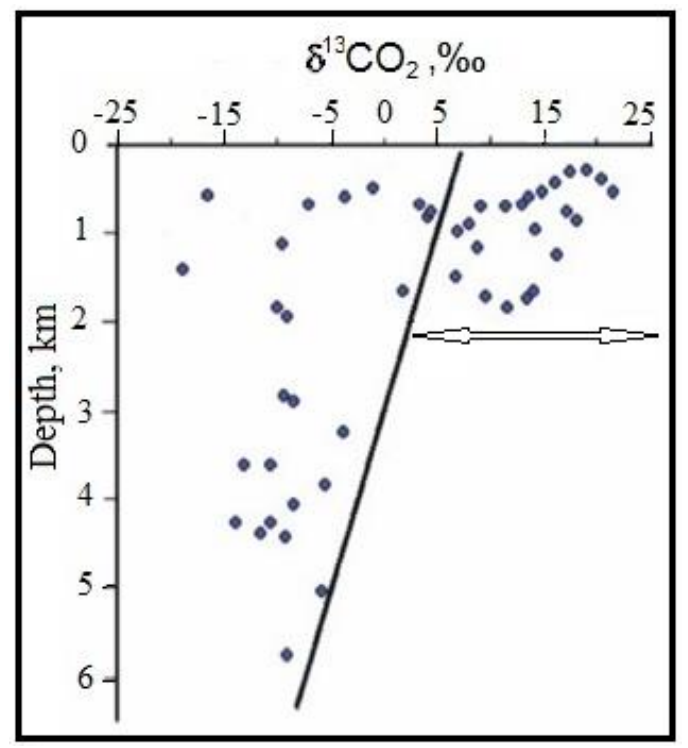

Figure 10. The carbon isotopic composition of carbon dioxide in gases of petroleum fields vs. depth

The mechanism of oil biodegradation is able to explain the nature of isotopically heavy $\mathrm{CO}_{2}$ in gases of petroleum fields and mud volcanoes. The presence of isotopically super-heavy $\mathrm{CO}_{2}$ and the possibility of its generation by the oxidation of hydrocarbons were mentioned by Zarttman et al. (1961), Kissin and Pakhomov (1967), Galimov (1973), Irwin et al. (1977), Pallasser R.J. (2000) and Wilhelms et al. (2001).

This result is confirmed by the comparative analysis of distribution of $\delta^{13} \mathrm{C} \mathrm{CO}_{2}$ and $\mathrm{CH}_{4}$ for mud volcanoes separately with and without oil seeps (Fig. 11). The heaviest $\delta^{13} \mathrm{C}$ values of $\mathrm{CO}_{2}$ and the lowest $\delta^{13} \mathrm{C}$ values of $\mathrm{CH}_{4}$ are typical for mud volcanoes with oil seeps (Feyzullayev and Movsumova, 2010).

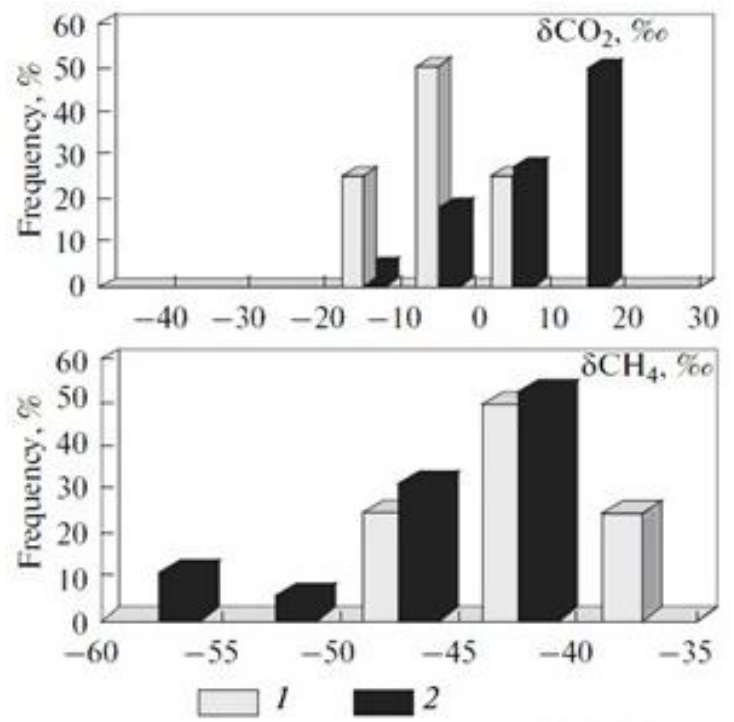

Figure 11. Histograms of the distribution of $\delta^{13} \mathrm{C} \mathrm{CO}_{2}$ values (in\%o) of $\mathrm{CO}_{2}$ and $\mathrm{CH}_{4}$ : (1) mud volcanoes without oil seeps and (2) mud volcanoes with oil seeps 


\subsection{Maturity of oils and gases}

A number of isotopic geochemical parameters are used for assessments of oil and gas maturity (Peters and Moldovan, 1993).

Isomerization of $\mathrm{C}_{29}$-ethylcholestanes and methyl-phenantrane index (MPI) are the most often used biomarker ratios for oil maturity assessments. Based on empirically derived relationships between values of these parameters and the thermal history of sedimentary basins their values are converted to equivalent vitrinite reflectance (Ro) values.

Gas maturity estimates are based on an empirically derived relation between carbon isotopic composition of HC gases and vitrinite reflectance (Ro) (Faber, 1987).

Values of isomerization of $\mathrm{C}_{29}$-ethylcholestanes ratio for studied oils vary between $0.3-0.5$ with an average value of 0.39 and a tendency for an increase in the direction of the regional subsidence of the strata. Such values indicate a low degree of maturity.

The majority of methyl-phenathrene index (MPI-1) values reported as vitrinite reflectance equivalence (Req.) are within 0.6-0.9 in agreement with the estimates of thermal maturity of oils corresponding to the upper part of oil window.

Values of trisnorhopane ratio $\mathrm{Ts} /(\mathrm{Ts}+\mathrm{Tm})$ vary within $0.21-0.30$ (0.26 average) and indicate that the oils were generated at different hydrocarbongenerating stages and/or from diverse source rocks.

There are no maturity differences between nondegraded oils and condensates.

Based on the estimates of the maturity of the gases from mud volcanoes (Feyzullayev et al., 2015), their gases migrate to the surface from considerable depths (7 to $15 \mathrm{~km}$ ), corresponding to the zone of generation of gas-condensate (vitrinite reflectance $\mathrm{R}_{0}=1.3-1.8 \%$ ). In this connection the primary gas must be fatty. Gas sampled in the quiet period of MV activity is predominantly methane and the gas is classified as dry. Gas wetness $\left\{100 \times\left(\mathrm{C}_{2}+/ \mathrm{C}_{1}+\right)\right\}$ values range from 0.01 to $0.62 \%$. The explanation is that during quite periods the gas migrates through the thick clay mass filling the channel of the volcano, accompanied by a contrasting gas chromatographic effect. However, during the eruption of mud volcanoes $\mathrm{HC}$ gases reach the surface through an open channel without a gas chromatographic effect. In this case the initial fatty composition of gases is reflected by the black color of the products of their combustion (Feyzullayev, 2010) (Fig. 12) and the detection of "frozen" drops of liquid HCs from the burning gas on the surface of the volcano.

As a whole the maturity estimates for mud volcano $\mathrm{HC}$ gases are in agreement with those for $\mathrm{HC}$ fields, varying within $1.30-2.10 \% \mathrm{R}_{\text {eq }}$. At the same time, slightly higher maturity of mud volcano gases is noted $\left(\mathrm{R}_{\mathrm{eq}}=1.55 \%\right.$ on average vs. $1.42 \%$ for reservoir gases).

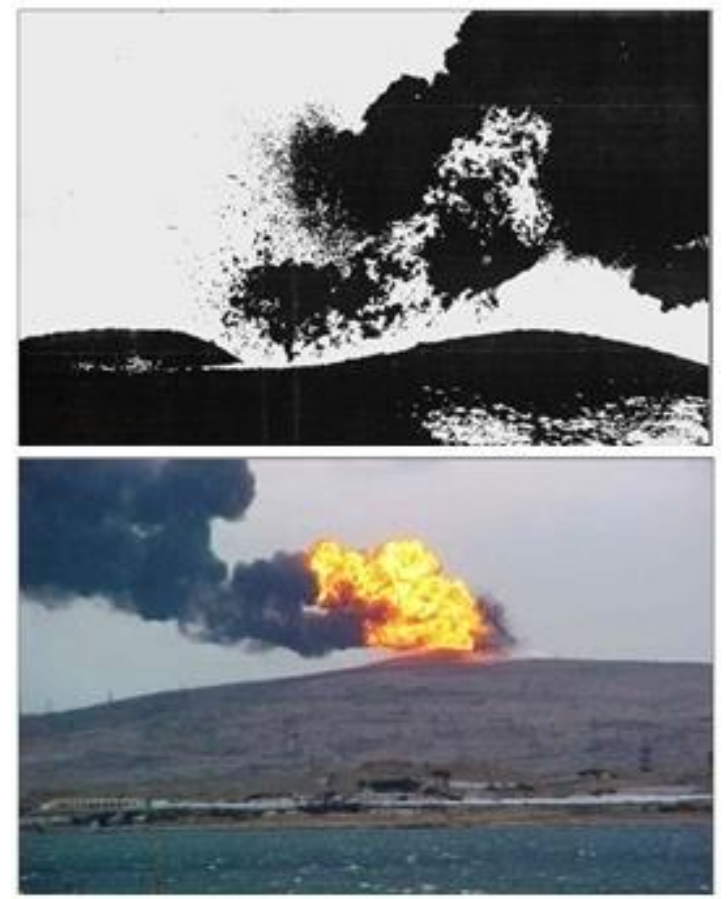

Figure 12. Eruptions of Lokbatan MV in 1997 (on the top) and 2001 years

The maturity of oils is lower in comparison with gas. The present-day maturity of the MV oils is $0.65 \%$ $-0.80 \% \mathrm{R}_{\text {eq. }}$ and agrees well with maturity of the reservoir oils, allowing one conclude that the MV oils are a product of the destruction of oil accumulation in structures, pierced by MV. Therefore the maximal depth of the MV oils does not exceed the depth of corresponding reservoir oils, about $4.9 \mathrm{~km}$ offshore (8 March field, well 580) and $5.3 \mathrm{~km}$ onshore (Kalamaddyn field, well 3) (Feyzullayev, 2012).

The stratigraphic locations of the HC sources change towards regional subsidence of strata (from southern slope of the Great Caucasus to the central deep buried part of SCB) from Mesozoic to Paleogene-Miocene (gas) and from Oligocene to Miocene (oil) (Feyzullayev and Aliyeva, 2003; Guliyev et al., 2004).

Using the relationship between $R_{0}$ and depth for the SCB a generalized model was created for vertical zonality of oil and gas generation in the SCB. The interval of oil and gas formation occupies a depth range of $5-15 \mathrm{~km}$, with a hypsometric shift between the zones of liquid and gas generation. The oil generation interval is confined to 5-9 $\mathrm{km}$ (peak generation at 7-8 km) and the gas source is located between 8 and $15 \mathrm{~km}$ (peak generation at 11-12 km) (Fig. 13). 


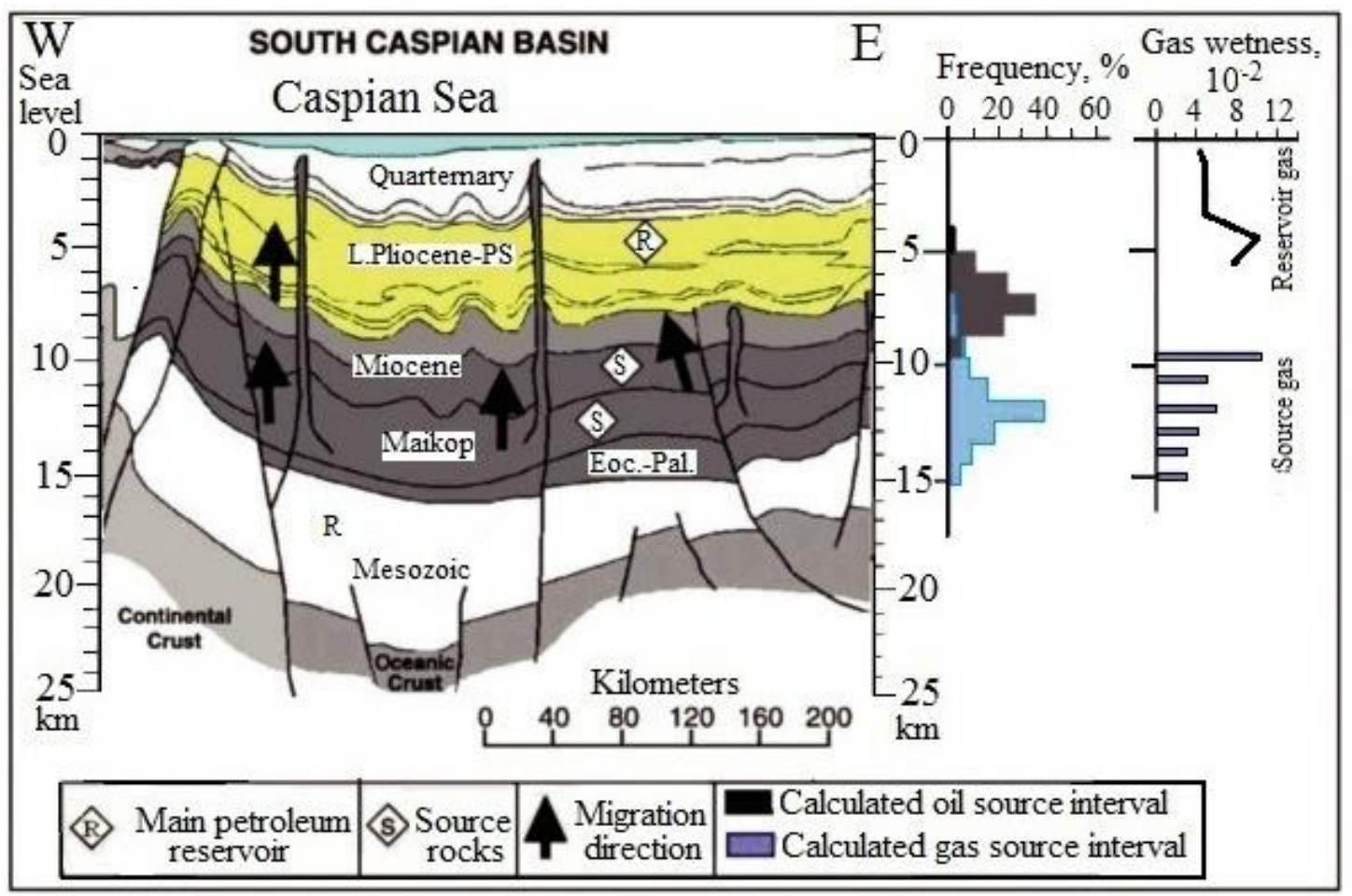

Figure 13. WE directed geological profile across the SCB with chart of calculated depths of oil and gas generation

\section{Conclusion}

Examination of hydrocarbons using gas chromatography and mass-spectrometry techniques showed that some oils are mixtures of biodegraded and non-biodegraded oils. Unaltered oils have similar n-alkane distributions indicating algae contribution typical for lacustrine, lagoonal or pelagic sedimentation environments.

Molecular characterization of selected oil samples indicates that most of the oils are sourced from similar Tertiary, slightly calcareous, mixed terrestrial-marine kerogen and have low to moderate organic maturities $\left(\mathrm{R}_{\mathrm{o}}=0.75-0.85\right)$.

Gas also has been derived from mixed marine organic-rich source facies (more humic and less anoxic). Such gas is not from the thermal destruction of oils.

Thermal disequilibrium from the rapid subsidence delayed hydrocarbon generation and increased the minimum depth required for the onset of liquid hydrocarbon generation. Several oils display characteristics consistent with multiple phases of trap charging.

\section{REFERENCES}

Faber E. About isotopic geochemistry of gaseous hydrocarbons. Erdol, Erdgas, Kohle, V. 103, Iss. 5, 1987, pp. 210-218 (in German).

Feyzullayev A.A. Mud volcanoes in the South Caspian basin: nature and estimated depth of its products. Natural Science, V. 4, № 7, 2012, pp. 445-453.
Oil-to-oil and source rock-to-oil correlations based on carbon isotopic ratios suggest that the Miocene interval (Diatom, Chokrak and Upper Maykop strata) has played the principal role in formation of commercial oil accumulations in Lower Pliocene reservoirs.

Liquid HCs and gas are generated by different stratigraphic intervals located at different depths. HC gases are sourced from the strata ranging in depth interval from 8 to $15 \mathrm{~km}$, with the tendency for increase in depth towards regional subsidence. Calculated depth of oil source corresponds to $5-9 \mathrm{~km}$.

The isotopically heavy carbon of the $\mathrm{CO}_{2}$ in gases of MVs and fields is most probably synthesized by the microbial destruction of hydrocarbons in an open system. This process takes place at shallow depths (no deeper than $2 \mathrm{~km}$ ) and, correspondingly, at low temperatures (no higher than $40^{\circ} \mathrm{C}$ for $\mathrm{SCB}$ ).

\section{Acknowledgment}

The author is deeply grateful to all colleagues who participated in the field and analytical studies.

\section{ЛИТЕРАТУРА}

Faber E. Zur isotopengeochemie gasformiger Kohlenwasserstoffe. Erdol, Erdgas, Kohle, V. 103, Iss. 5, 1987, pp. 210-218.

Feyzullayev A.A. Mud volcanoes in the South Caspian basin: nature and estimated depth of its products. Natural Science, V. 4, № 7, 2012, pp. 445-453. 
Feyzullayev A.A. Physicochemical interactions in the sedimentary rock - fluid system in the South Caspian basin in connection with oil-gas ontogenesis. Proceedings of ANAS, The Sciences of Earth, № 4, 2010, pp. 28-45 (in Russian).

Feyzullayev A.A., Aliyeva Es.A. Estimation of the various source rocks contribution in oil pools formation. Proceedings of EAGE 65 Conference and Exhibition. Stavanger. Norway, 2-5 June, 2003.

Feyzullayev A.A., Movsumova U.A. The nature of the isotopically heavy carbon composition of carbon dioxide and bicarbonates in the waters of mud volcanoes in Azerbaijan. Geochemistry International, V. 48, № 5, 2010, pp. 517-522.

Feyzullayev A.A., Tagiyev M.F., Lerche I. On the origin of hydrocarbons in the main Lower Pliocene reservoirs of the South Caspian Basin, Azerbaijan. Energy, Exploration \& Exploitation, V. 33, № 1, 2015, pp. 1-14.

Galimov E.M. Carbon isotopes in oil and gas geology. Nedra. Moscow, 1973, 384 p. (in Russian).

Guliyev I.S., Feyzullayev A.A., Huseynov D.A. Geochemical features and source of fluids of mud volcanoes in South Caspian basin in lights of new data at isotopes $\mathrm{C}, \mathrm{H}$, and $\mathrm{O}$. Geochimiya, № 7, 2004, 792-800 (in Russian).

Irwin H., Curtis C., Coleman M. Isotopic evidence for source of diagenetic carbonates formed during burial of organic rich sediments. Nature, V. 269, Iss. 5625, 1977, pp. 209-213.

Kissin I.G., Pakhomov S.N. On the possibility of generation of hydrocarbonic acid in the interiors under moderately high temperatures. Doklady AS of the USSR, V. 174, № 2 , 1967, pp. 451-454 (in Russian).

Marzi R., Torkelson, B.E., Olson R.K. A revised carbon preference index. Organic Geochemistry, V. 20, № 8, 1993, pp. 1303-1306.

Pallasser R.J. Recognising biodegradation in gas/oil accumulations through the ${ }^{13} \mathrm{C}$ compositions of gas components. Org. Geochem., V. 31, № 12, 2000, pp. 1363-1373.

Peters K.E., Moldowan J.M. The biomarker guide: interpreting molecular fossils in petroleum and ancient sediments. Prentice Hall. Englewood Cliffs, New Jersey, 1993, 363 p.

Valyaev B.M., Grinchenko Yu.I. Source of isotopically "ultraheavy" carbon dioxide in natural gases. In: Proceedings of 10th AllUnion symposium on Stable Isotopes in Geochemistry, Moscow, Russia, 1984, p. 170 (in Russian).

Wilhelms A., Larter S.R., Head I. et al. Biodegradation of oil in uplifted basins prevented by deep burial sterilization. Nature, V. 411, 2001, pp. 1034-1037.

Zartman R.E., Wasserburg G.J., Reynolds J.H. Helium, argon and carbon in some natural gases. J. Geophys. Res., V. 66, 1961, pp. 277-286.
Feyzullayev A.A., Aliyeva Es.A. Estimation of the various source rocks contribution in oil pools formation. Proceedings of EAGE 65 Conference and Exhibition. Stavanger. Norway, 2-5 June, 2003.

Feyizullayev A.A., Movsumova U.A. The nature of the isotopically heavy carbon composition of carbon dioxide and bicarbonates in the waters of mud volcanoes in Azerbaijan. Geochemistry International, V. 48, № 5, 2010, pp. 517-522.

Feyzullayev A.A., Tagiyev M.F., Lerche I. On the origin of hydrocarbons in the main Lower Pliocene reservoirs of the South Caspian Basin, Azerbaijan. Energy, Exploration \& Exploitation, V. 33, № 1, 2015, pp. 1-14.

Irwin H., Curtis C., Coleman M. Isotopic evidence for source of diagenetic carbonates formed during burial of organic rich sediments. Nature, V. 269, Iss. 5625, 1977, pp. 209-213.

Marzi R., Torkelson, B.E., Olson R.K. A revised carbon preference index. Organic Geochemistry, V. 20, № 8, 1993, pp. 1303-1306.

Pallasser R.J. Recognising biodegradation in gas/oil accumulations through the ${ }^{13} \mathrm{C}$ compositions of gas components. Org. Geochem., V. 31, № 12, 2000, pp. 1363-1373.

Peters K.E., Moldowan J.M. The biomarker guide: interpreting molecular fossils in petroleum and ancient sediments. Prentice Hall. Englewood Cliffs, New Jersey, 1993, 363 p.

Wilhelms A., Larter S.R., Head I. et al. Biodegradation of oil in uplifted basins prevented by deep burial sterilization. $\mathrm{Na}$ ture, V. 411, 2001, pp. 1034-1037.

Zartman R.E., Wasserburg G.J., Reynolds J.H. Helium, argon and carbon in some natural gases. J. Geophys. Res., V. 66, 1961, pp. 277-286.

Валяев Б.М., Гринченко Ю.И. Источник изотопно-тяжелой углекислоты в природных газах. В материалах 10 Всесоюзного симпозиума по стабильным изотопам в геохимии. Москва, Россия, 1984, с.170.

Галимов. Э.М. Изотопы углерода в нефтегазовой геологии. Недра. Москва, 1973, 383 с.

Гулиев И.С., Фейзуллаев А.А., Гусейнов Д.А. Геохимические особенности и источники флюидов грязевых вулканов Южно-Каспийского осадочного бассейна в свете новых данных по изотопии $\mathrm{C}, \mathrm{H}$, и О. Геохимия, № 7 , 2004, с. 792-800.

Киссин И.Г., Пахомов С.Н. О возможности генерации углекислоты в недрах при умеренно высоких температурах. Докл. АН СССР, Т. 174, № 2, 1967, с. 451-454.

Фейзуллаев А.А. Физико-химические взаимодействия в системе осадочная порода-флюид в Южно-Каспийском бассейне в связи с онтогенезом нефти и газа. Известия НАН Азербайджана. Науки о Земле, № 4, 2010, с. 28-45.

\title{
ИЗОТОПНО-ГЕОХИМИЧЕСКАЯ ХАРАКТЕРИСТИКА УГЛЕВОДОРОДОВ СЕВЕРО-ЗАПАДНОГО ФЛАНГА ЮЖНО-КАСПИЙСКОГО БАССЕЙНА
}

\author{
Фейзуллаев А.А. \\ Институт геологии и геофизики НАНА \\ AZ1148, г.Баку, npосп. Г.Джавида, 119: fakper@gmail.com
}

Резюме. В данной статье подробно рассматриваются различные аспекты изотопно-геохимических особенностей нефтей и газов СЗ борта Южно-Каспийского бассейна (Гобустан, западный Абшерон и прилегающая прибрежная зона), где естественные проявления нефти и газа связаны с тектоническими нарушениями и грязевыми вулканами (ГВ). Нефти ГВ биодеградированы, имеют преимущественно нафтен-парафиновую основу с содержанием серы менее $0,5 \%$. Образцы нефти и углеводородного экстракта материнских пород анализировались с помощью газовой хроматографии, масс-спектрометрии и их комбинации (биомаркерный анализ). Проведена корреляция нефть - нефть и нефть - материнская порода, и установлено, что нефти соответствуют породам третичного возраста с органическими фациями, накопленными в глубоководных условиях с некоторым вкладом наземного органического материала. Нефти характеризуются низкой или умеренной зрелостью $(\mathrm{Ro}=0,75-0,85)$. Зависимость между изотопным составом углерода (ИСУ) алифатической и ароматической фракций нефтей и экстрактов пород показывает, что источником промышленных запасов нефти в продуктивной толще (нижний плиоцен) 


\title{
Geology and geophysics
}

являются в основном миоценовые отложения (диатом, чокрак и верхний майкоп). Источником газов является осадочный чехол, о чем свидетельствуют значения отношения ${ }^{3} \mathrm{He} /{ }^{4} \mathrm{He}$. Газы также были образованы из смешанной морской (преобладает) и наземной органической фаций. Газы не являются продуктом термического крекинга нефтей. Расчетная глубина источника нефти соответствует 6,1-8,6 км (источника газа - от 8,1 до 15,8 км). Изотопно-тяжелый ИСУ $\mathrm{CO}_{2}$ в газах, скорее всего, связан с микробным разрушением углеводородов на небольших глубинах (не глубже 2 км).

Ключевые слова: нефть, газ, материнские породы, органическое вещество, геохимия, корреляция. Южно-Каспийский бассейн

\section{CəNUBi XəZəR HÖVZəSININ ŞIMAL-QכRB CINAHINDA KARBOHIDROGENLəRIN IZOTOP-GEOKIMYYəVI SəCIYYəSi}

\author{
Feyzullayev Ә.Ә. \\ AMEA Geologiya va Geofizika Institutu \\ AZ1143, Bakı şəh., H.Cavid prosp.,119: fakper@gmail.com
}

Xülasə. Bu məqalədə Cənubi Xəzər hövzəsində (Qobustan, Qərbi Abşeron rayonları və bitişik sahil zonası) neft və qazın izotopgeokimyəvi xüsusiyyətlərinin müxtəlif aspektləri təhlil edilir. Burada geniış yayılmış neft və qazın təbii təzahürləri tektonik qırılmalar və palçıq vulkanları (PV) ilə əlaqədardır. Bioloji aşınmaya məruz qalmış və kükürdün miqdarı $0,5 \%$-dən az olan PV neftləriı, əsasən, naften-parafin tərkiblidir. Neftin və ana süxurların karbohidrogen ekstraktının nümunələri qaz- xromatoqrafiya, mass-spektrometriya və onların kombinasiyası (biomarker analizi) üsullarının köməyi ilə öyrənilmişdir. Neft-neft və neft-ana süxur korrelyasiyası aparılmış və müəyyən edilmişdir ki, neftlər, əsasən, dərinsu şəraitində yığılmış Miosen yaşlı üzvi materialdan əmələ gəlmişdir. Neftlərin yetkinliyi aşağ 1 və ya orta dərəcəyə $($ Ro $=0,75-0,85)$ uyğundur. Neftlərin və süxur ekstraktlarının alifatik və aromatik fraksiyaların karbonunun izotop tərkibləri (KİT) arasındak1 asılılıq Məhsuldar qatda (alt Pliosen) olan sənae neft ehtiyatlarının mənbəyinin əsasən Miosen çöküntüləri (Diatom, Çokrak və üst Maykop) olduğunu göstərir. Qazların mənbəyi ${ }^{3} \mathrm{He} /{ }^{4} \mathrm{He}$ nisbətinin qiymətlərinə görə çöküntü örtüyüdür. Qazlar da qarışıq dəniz (dominant) və yerüstü üzvi fasiyalardan əmələ gəlmişdir və onlar neftlərin termal krekinqinin məhsulu deyil. Hesablanmış neft mənbəyin dərinliyi 6,1-8,6 km-ə bərabərdir (qaz mənbəyi 8,1-dən 15,8 km-ə qədərdir). Qazlarda $\mathrm{CO}_{2}$ ağır KİT-nin dayaz dərinliklərdə (2 km-dən dərin olmayan) karbohidrogenlərin mikrobial dağılması ilə əlaqədardır.

Açar sözlor: neft, qaz, ana süxurlar, üzvi maddə, geokimya, korrelyasiya, Cənubi Xəzər hövzəsi 